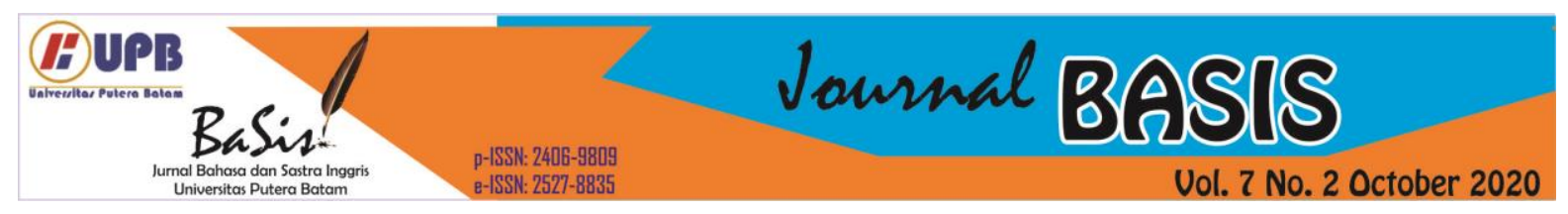

\title{
THE AREAS OF MISSPELLING \\ PHONEME IN SANDIAGA UNO'S SPEECH: A PHONOLOGICAL APPROACH
}

\author{
Riel Akmal Ikhsan \\ University of Putera Batam, Batam Island, Indonesia \\ rielakmalkhsn@gmail.com \\ Ambalegin \\ University of Putera Batam, Batam Island, Indonesia \\ Abhi140475@gmail.com
}

\begin{abstract}
This study is chosen to be the main subject in the term of linguistic study due to the popular issue in linguistic area, that is phonology, one of the focused subjects in linguistic aspect in English. Phonology also has several impacts to the people who involve in the language and linguistic subject and matter. Based from the related research, it is about the misspelling phoneme areas in the speech made by a public figure in Indonesia, who is Sandiaga Uno. The main purpose for this research is to find out the areas of misspelling phoneme made by Sandiaga Uno in his speech as the governor candidate for Jakarta, candidate for vice president and also as the public figure in Indonesia. The main result is the phenomenon of misspelling phoneme was existent in the area of dental like the phoneme $/ \Theta /$, area of glottal stop such the sound $/ \mathrm{D} /$, and also the area of stop such the phoneme $/ \mathrm{J} /$. This present research will use the phonological approach in linguistic study. Moreover, this present research will use the descriptive qualitative method in analysing and presenting the result of the research. This present research will analyse about the misspelling phoneme areas in phonology study. The data source will be taken from the speech by Sandiaga Uno. The approach that will be used for this present research will be the phonological approach in Linguistics.
\end{abstract}

Keywords: British English, misspelling, phonology, phoneme.

\section{INTRODUCTION}

The study of sound pattern in the area of linguistic is called as phonology. The general meaning of phonology is a part in pure linguistic study which explains about the sound pattern of language and how the words get said within the sound from the human and the system from the phonological rules with the identification (Yavas, 2011). That means the phonology is related to the sound of a language and how to pronounce the word in a language.
Usually, people have their own opinion that phonology and pronunciation are the same but in fact that phonology is more structured than pronunciation. In phonology, there are the phonetic symbol, phonemes, phones and allophones, syllable, and other units. Not alike the pronunciation side which contains mostly in how to pronounce and the phonetic spelling like vowels and consonants. Phonology is structured because every 
part in pronunciation is come from the phonology material (Yule, 2010).

Phonology is used in reality, even, it comes to the people naturally when the speaking condition happens. When the group of people in social term try to speak English in public and society, the phonological thing occured. The evidence that related to the phonology structure, it is about the way they change the phoneme in one word or pronunciation of each people. This problem is also called as a misleading in pronouncing the correct pronunciation. Furthermore, this fact will be related to the language acquisition first. Generally, there are three types of language for human, there are the first language or mother tongue, second language or the formal language, and the third language is foreign language. People who learn about the first language have started their knowledge with their parents or social life in childhood with the pronunciation related with the first language. They learn about how the words are made and also how to say the words in a correct way - still known as pronunciation and how to articulate the words. People with first language will master their language until the adult period; and this first language usually affected to the cultural language but not always be like this statement from Yule in 2010. The second language would talk about the formal language used in daily use. People take the second language in formal situation, to the people which they do not know really close, and also for the occasion situation. After all, the language and pronunciation are connected to each other as a part in communicating process and inside the process itself, the problems that occurred will be known as the process of getting the nature of language by the society of people. The problem inside these all statements that talks about the misspelling of phoneme, is definitely related to the phenomenon in phonology area (Yule, 2010).

The acquisition of English as foreign language is also needed to be concerned in this area of study. In Indonesia, English is a foreign language, and it is rarely used in daily use. People use English only for several reasons: for connecting with the foreign communication, business, or in education field. The general understanding could be said that English is formally learned in the school, but when the students get back home, they use Indonesian to speak because there are no places to practise the English. Moreover, because of there is no time to practise English, they say the words in English in an incorrect way. The reason is available; that English in the school of Indonesian just gets learned in the study of grammar. How rare to see the school would teach the phonology, even in a very simple way that related to the phonetic symbol, due to the case of English as a foreign language. This case will be called as a rarity due to the acquisition of English as a foreign language in Indonesia.

The phenomenon here inside the previous study will have relation in the term of phonology; related to the phonological approach, a study about the inconsistency in English pronunciation analysed by Ambalegin and Arianto in 2019. The theory that was used in this research was the theory from George Yule, and also the theory from the expert named Finegan and Kelly. The related theory was applied in the area of society with English as a foreign language in acquisition with the qualitative method. This journal talks about the different sounds in pronouncing the vowel sound 
in English that happened in general in society as the phenomenon of inconsistency. For instance, when the people saw the alphabet or the letter ' $a$ ' as the schwa phenomenon, they made some variation in articulating the sound of the phoneme, they could make the sound such as the sound $/ \mathrm{a} /, / \mathrm{p} /$, and the sound $/ \mathrm{o} /$. At the conclusion, this study made a result that the areas of inconsistency in English pronunciation occur in the same letter different sounds, same sound different letters, silent letters and sound production with no letters.

Phenomenon of incorrect pronunciation that is also related to the area of phonology and assimilation occurred also in the other previous study here analysed by (Ambalegin \& Hulu, 2019). The mispronunciation made by the people here in the related study occurred as the result of having a little skill in speaking the foreign language. The use of Received Pronunciation is calculable as the standard English in the area of pronunciation. For instance, the consonant sounds such as $/ \delta /, / \theta /, /$ th $/, / \mathrm{z} /$, $/ \mathrm{r} /, \quad / \mathrm{f} /, \quad / \mathrm{f} /, \quad / \mathrm{d} / \mathrm{J} /, \quad$ are pronounced incorrectly due to the different language for the foreign speaker of language in Indonesia. This study used the qualitative method and collected the data by having the observational method and the result was presented in several factors, like the use of mother tongue, phonetic understanding, and also about the background of the person in language area.

The other phenomena that related to the phonological field and misspelling phoneme area occurred when the researcher was still in the high school in 2016. When the teacher of English language taught the lesson about grammar, the teacher asked the students to pronounce the sentence 'thank you', and one of the students was the researcher of this phonological approach. That time, all of the students pronounced 'thank you' as /ten'kiu/, not the correct pronunciation that is /өæn'кJu/. Based from this phenomenon, the researcher can take the small analysis that the phoneme $/ \mathrm{A} /$ had been changed into phoneme / $\mathrm{t} /$, and this condition is called as misspelling phoneme area in phonology of English (Yule, 2010).

Phonology is structured in a varied pattern and also connected to the function of language with the acquisition of a language to the community. To be known also, that English acquisition as the foreign language in Indonesia is proved, exactly in the related speech of Sandiaga Uno for this study and research as the main point, and he is likely available in speaking English even though by saying only the words or phrases in English, or even more than just the words. Person here in Indonesia as a non-native speaker of English, Sandiaga Uno, a governor candidate for Jakarta that is being analysed here in this study, is able to speak up in English, with the related pronunciation of him. In contrast, the area of misspelling phoneme occurred by Sandiaga Uno. The phenomena that occurred in Sandiaga Uno's speech can be related to phenomenon in English phonology, where English is famous in several areas in Indonesia, for instance in the market advertisement, public announcement, and information in general. These all media use English to attract people in reading their advertisement. In contrast, when they pronounce the words, the area of misspelling phoneme then occurred. This problem then hooked the research to 
examine more about the misspelling phoneme area in phonology.

\section{LITERATURE REVIEW}

\subsection{The area of phoneme}

1. Place of articulation

\section{a. Bilabial}

The sound that is made by the formation of using the upper and lower side of lips is known as the bilabial sound. It is called as the bilabial due to the use of two features which is 'bi', and both sides of lips are 'labia'. The sounds that are created from this formation are the sounds like pet, beg, and math. In the specific way, the sound $/ \mathrm{p} /$ is voiceless, whilst the sounds $/ \mathrm{b} /$ and $/ \mathrm{m} /$ are the voiced sounds. In the other case, the sound of $/ \mathrm{w} /$ in the words like wait and work is also the phenomenon of bilabial. It is related to the beginning of the sound (Yule, 2010).

\section{b. Labiodental}

The sound that is created by the upper side of teeth and the lower part of lip is known as the labiodental. These kinds of sound can be found in the words like van and fall. In the last part of the sound, these sounds also can be seen in the words like have and leaf. The symbols for the presented sounds are in the symbols /f/ as the voiceless sound and /v/ as the voiced one. Some words like tough and phrase are different in spelling term, but they are pronounced by using the sound /f/ (Yule, 2010).

\section{c. Dental}

The sound that is formed by the end side of tongue behind the upper side of front teeth is called as the dental sound. This type of sound can be recognised in the sounds like think and thick. For this first one is called as the voiceless dental and existent in the symbol $/ \Theta /$. For the voiced sound, it is presented in the sign
$/ \%$, this sound can be found in the words like thereupon and thereby. This sound is also the part of consonant side (Yule, 2010).

\section{d. Alveolar}

The sounds that are articulated with the use of the front part of the tongue on the side of high place in surface is called as the alveolar sound. This type of material can be found in several words. For examples, as the related materials in the words like tea, seal, deep, zucchini, and name. these all words use the alveolar sound. The symbols of phoneme to be shown as in the form $/ t /, / s /$, these first two sounds are voiceless, and $/ \mathrm{d} /, / \mathrm{n} /$, and /z/ are the voiced sounds (Yule, 2010).

\section{e. Palatal}

The sound that appeared in the back side behind the alveolar structure with the hard side on the mouth roof is called as the palatal sound. These sounds can be found in the voiceless areas, and presented in the form $/ \mathrm{J} /$ and $/ \mathrm{t} /$. In the words of English, it can be seen in the words like child and shield. In the other side, for the voiced sound, it is represented in the word jug. This jug uses the phoneme $/ \mathrm{d} z /$ on the first sound (Yule, 2010).

\section{f. Glottal}

The sound in the letter $/ \mathrm{h} /$ that is used in the words hook and hush is the glottal sound. This sound is made by having no active side on tongue and other side of mouth. This sound is related to the voiceless sound. For the other materials, this sound is also existent in the other words like whom and whole. This sound has the different name like the sound of glottis (Yule, 2010). 


\section{Manner of articulation}

\section{A. Stop}

This type of sound is created by the air flow that is stopped and let the related flow walk suddenly. This type of sound is stopped and blocked by the manner of articulating. The related sound in this type are presented in the phoneme $/ \mathrm{p} /, / \mathrm{g} /, / \mathrm{k} /, / \mathrm{t} /, / \mathrm{b} /$, and $/ \mathrm{d} /$. the words as the example can be seen in the words like pink, grab, kind, top, big, and dice. This sound also contains the effect of stopping in the air flow (Yule, 2010).

\section{B. Fricative}

This kind of sound is made by covering the air flow and having the push on the air through the very limited beginning. The collections of the sound are shown in the sounds like /f/, /v/, /s/, $/ \mathrm{z} /, / \mathrm{J} /, / \mathrm{z} /, / \Theta /$, and $/ \%$. These all sounds are resulted by the pushed air and the air can be felt by putting our hand in front our mouth. The sound contains the air and the related push from the speaker. The related sounds can be seen in the words like sheep, vision, and zoo (Yule, 2010).

\section{Affricate}

This sound is developed by the sudden stop and air flow with the rubbing act inside the mouth, it is called as the affricate. For instance, these kinds of sound can be found in the words like cheek and jump. The symbols to represent the related sounds are the phoneme $/ \mathrm{t} /$ and /dz/. The sound in the word cheek is known as the voiceless sound. In the other side, the voiced term is presented in the word jump (Yule, 2010).

\section{Liquid}

This form of sound is called as liquid because of the relation with the tongue and the flow of the air inside the mouth. In the real words in English, as what is written in the words leave and right. They all are the voiced sounds.
These sounds are presented in the form /1/ and $/ \mathrm{r} /$. The related sounds are produced by the form of raising and curling the tip of tongue in the mouth (Yule, 2010).

\section{E. Glottal stop and flap}

This term of stop and flap in glottal is presented by the symbols like $/ \mathrm{R} / \mathrm{h} / \mathrm{D} /$ and $/ \mathrm{r} /$ inside the pronunciation. This glottal stop can be found in the word like uh-huh. For the glottal flap also can be seen in the word like butter and paddy. This feature is related to the consonant sound in English pronunciation. The speech with the related material is recognized as the part in understanding the middle consonant sound (Yule, 2010).

\section{Vowel}

The sounds that are produced with no relation with the flow of the air are considered to be the vowel sound in pronunciation. Unlike the consonant sounds, vowels are likely to be individual in sounding process. Vowel sounds are the sound in a language with the air flow process in creating the articulation stage (Mcmahon, 2002). The process with tongue is still needed here, even though the flow of the air is usually free in motion. The vowels are divided into several parts, like in the front vowels such as the sounds $/ \mathrm{i} /, / \mathrm{I} /, / \mathrm{e} /, / \varepsilon /, / \Re /$, and the central vowels such as the phonemes $/ \partial /$, $/ \Lambda /$, and $/ \mathrm{a} /$, and the back vowels are the phonemes $/ \mathrm{u} /, / \mathrm{\sigma} / \mathrm{/o} / \mathrm{/} / \mathrm{a} /$, and $/ \%$. These all are the materials for the vowels in English (Yule, 2010).

\section{RESEARCH METHOD}

This present research will be the descriptive qualitative research. This qualitative research will focus on the image term and text in examining the data. This qualitative research talks about the research in social phenomenon and the real case in society. The activities that 
are involved in this research of qualitative are comments, interpreting, validating, and indicating the outcome of the study. These all the strategies in creating the qualitative research method (John W. Creswell-Research Design_ Qualitative, Quantitative, and Mixed Method Approaches-SAGE Publications (2013).pdf, 2013).

The data of the research was taken by using the method of observational. This observational method is a way in collecting the data by having the observation on the data. The researcher of this research puts an observation in having data by watching the speech, understanding the utterance, and listening to the speech made by Sandiaga Uno as the public figure in Indonesia. The researcher does not take place in involving the data in the related speech. This means, the name of the technique is the non-participatory technique in analysing the data (Sudaryanto, 2015).

\section{RESULT AND DISCUSSION}

The related research has produced the results and will be presented here in the form of table, made by Sandiaga Uno in his speech as the public figure in

\begin{tabular}{|c|c|c|c|c|}
\hline No. & Word & $\begin{array}{l}\text { British } \\
\text { English }\end{array}$ & $\begin{array}{c}\text { Speech by } \\
\text { Sandiaga } \\
\text { Uno }\end{array}$ & $\begin{array}{c}\text { Misspe } \\
\text { lling } \\
\text { phone } \\
\text { me } \\
\text { area }\end{array}$ \\
\hline 01. & Think & /eInk/ & $/ \operatorname{tin} /$ & $\begin{array}{ll}/ \Theta / & \text { to } \\
/ \mathrm{t} / & \end{array}$ \\
\hline 02. & $\begin{array}{l}\text { Intern } \\
\text { et }\end{array}$ & $\begin{array}{l}\text { /'Intən } \\
\text { et/ }\end{array}$ & /'Intərnet/ & $\begin{array}{l}\text { The } \\
\text { phone } \\
\text { me /r/ } \\
\text { is } \\
\text { added }\end{array}$ \\
\hline 03. & $\begin{array}{l}\text { Soluti } \\
\text { on }\end{array}$ & $\begin{array}{l}\text { /sə'lu: } \\
\text { n/ }\end{array}$ & /sDlufn/ & $\begin{array}{ll}/ \partial / & \text { to } \\
/ \mathrm{D} / & \end{array}$ \\
\hline 04. & $\begin{array}{l}\text { Prese } \\
n t\end{array}$ & $\begin{array}{l}\text { /pri'ze } \\
\text { nt/ }\end{array}$ & /prisen/ & $\begin{array}{ll}/ \mathrm{z} / & \text { to } \\
/ \mathrm{s} / & \end{array}$ \\
\hline
\end{tabular}

Indonesia. The public figure like Sandiaga Uno is an Indonesian man who lives in Indonesia, and raised in Indonesia. For the general knowledge, that English is a foreign language in Indonesia. This condition makes English is pronounced differently by people in Indonesia, especially if it is based from the background of people with different culture and social condition. In the speech made by Sandiaga Uno, Sandiaga has made several phenomena of misspelling phoneme area in English, as what will be presented in the related table below. The tool for analysing the correct pronunciation is the Oxford dictionary. The data of the misspelling phoneme phenomenon will be equalised with the Oxford dictionary which uses the British English as the standard use for English speech (Victoria Bull, 2008). This Oxford dictionary will be structured also with the advanced dictionary of Oxford (Oxford advanced learner's dictionary, n.d.).

\subsection{The area of misspelling phoneme}

Table 1. The area of misspelling phoneme made by Sandiaga Uno in his speech as the public figure in indonesia

\begin{tabular}{|c|c|c|c|c|}
\hline 05. & Want & /wont/ & /wan/ & $\begin{array}{ll}/ \mathrm{D} / & \text { to } \\
/ \mathrm{a} / & \end{array}$ \\
\hline 06. & $\begin{array}{l}\text { Provi } \\
\text { ding }\end{array}$ & $\begin{array}{l}\text { /pre'va } \\
\text { Idin/ }\end{array}$ & /provardin/ & $\begin{array}{ll}/ \mathrm{a} / & \text { to } \\
/ \mathrm{D} / & \\
\end{array}$ \\
\hline 07. & $\begin{array}{l}\text { Acces } \\
\mathrm{s}\end{array}$ & $\begin{array}{l}\text { /'ækses } \\
\end{array}$ & /ekses/ & $\begin{array}{ll}/ æ / & \text { to } \\
/ \mathrm{e} / & \end{array}$ \\
\hline 08. & $\begin{array}{l}\text { Botto } \\
\text { m }\end{array}$ & $\begin{array}{l}\text { /'bDto } \\
\mathrm{m} /\end{array}$ & $/ \mathrm{b} \Lambda \mathrm{təm} /$ & $\begin{array}{ll}\mathrm{D} / & \text { to } \\
\mathrm{/} / \mathrm{S} & \\
\end{array}$ \\
\hline 09. & Better & $\begin{array}{l}\text { /'beto(r } \\
\text { )/ }\end{array}$ & /betər/ & $\begin{array}{l}\text { The } \\
\text { sound } \\
/ \mathrm{r} / \quad \text { is } \\
\text { pronou } \\
\text { nced }\end{array}$ \\
\hline 10. & $\begin{array}{l}\text { Educa } \\
\text { tion }\end{array}$ & $\begin{array}{l}\text { l,edzu' } \\
\text { keIfn/ }\end{array}$ & /edukeIJn/ & $\begin{array}{l}/ \mathrm{d}_{3} / \text { to } \\
/ \mathrm{d} /\end{array}$ \\
\hline 11. & $\begin{array}{l}\text { Throu } \\
\text { gh }\end{array}$ & /eru:/ & /tru:/ & $\begin{array}{ll}/ \mathrm{e} / & \text { to } \\
/ \mathrm{t} / & \\
\end{array}$ \\
\hline 12. & Techn & /tek'nd & /teknolddzi/ & $/ \mathrm{a} /$ \\
\hline
\end{tabular}




\begin{tabular}{|c|c|c|c|c|}
\hline & ology & lədzi// & & /D/ \\
\hline 13. & $\begin{array}{l}\text { Infrast } \\
\text { ructur } \\
\text { e }\end{array}$ & $\begin{array}{l}\text { /'infrəs } \\
\operatorname{tr} \Lambda \mathrm{kt} \int \partial( \\
\mathrm{r}) /\end{array}$ & $\begin{array}{l}\text { /infrastr } \Delta \mathrm{kt} \int \\
\text { ər/ }\end{array}$ & $\begin{array}{ll}/ \partial / & \text { to } \\
/ \mathrm{a} / & \end{array}$ \\
\hline
\end{tabular}

\subsection{Discussion}

a. Misspelling phoneme in dental

The sound that is formed by the end side of tongue behind the upper side of front teeth is called as the dental sound. This type of sound can be recognised in the sounds like think and thick. For this first one is called as the voiceless dental and existent in the symbol $/ \Theta /$. For the voiced sound, it is presented in the sign $/ \%$, the phenomenon of misspelling phoneme into $/ \mathrm{t} /$ is existent here made by Sandiaga Uno in his speech. This sound is also the part of consonant side (Yule, 2010).

b. Misspelling phoneme in glottal stop

This term of stop and flap in glottal is presented by the symbols like $/ \mathrm{R} /, / \mathrm{D} /$ and $/ \mathrm{r} /$ inside the pronunciation. This glottal stop can be found in the word like uh-huh. For the glottal flap also can be seen in the word like butter and paddy. The related misspelling phoneme in stop of glottal occurred in Sandiaga Uno's speech, when Sandiaga misspelled the phoneme $/ \mathrm{D} /$ into $/ \Lambda /$. The speech with the related material is recognized as the part in understanding the middle consonant sound (Yule, 2010).

\section{c. Misspelling phoneme in palatal}

The sound that appeared in the back side behind the alveolar structure with the hard side on the mouth roof is called as the palatal sound. These sounds can be found in the voiceless areas, and presented in the form $/ \mathrm{J} /$ and $/ \mathrm{t} /$. The speech made by Sandiaga Uno contains

\begin{tabular}{|c|c|c|c|c|}
\hline 14. & $\begin{array}{l}\text { Educa } \\
\text { te }\end{array}$ & $\begin{array}{l}\text { /'edzuk } \\
\text { eit// }\end{array}$ & /edukert/ & $\begin{array}{l}/ \mathrm{d} 3 / \text { to } \\
/ \mathrm{d} /\end{array}$ \\
\hline 15. & $\begin{array}{l}\text { Empo } \\
\text { wer }\end{array}$ & $\begin{array}{l}\text { /Im'pa } \\
\text { ઇə(r)/ }\end{array}$ & /empaøər/ & $\begin{array}{ll}/ \mathrm{I} / & \text { to } \\
/ \mathrm{e} / & \end{array}$ \\
\hline
\end{tabular}

misspelling phoneme in the area of palatal, as the phoneme $/ \mathrm{d} z /$ is misspelled into phoneme $/ \mathrm{d} /$. In the other side, for the voiced sound, it is represented in the word jug. This jug uses the phoneme /dz/ on the first sound (Yule, 2010).

\subsection{The factor of misspelling phoneme in pronunciation}

The misspelling phoneme area in phonology is existent in reality, even, it comes to the people in general when the speaking condition happens. If it comes to the beginning theory of phonology, the understanding of language and how to bring it in society will be the main reason of the problem in articulating the word in a language. When the group of people in social term try to speak English in public and society, the phonological thing occured. The evidence that related to the phonology pattern, it is about the way they change the phoneme in one word or pronunciation of each community. This phenomenon is also called as a misspelling phoneme in pronouncing the correct pronunciation. Furthermore, this fact will be related to the language acquisition first. Generally, there are three kinds of language for people, there are the first language or mother tongue, second language or the formal language, and the third language is foreign language. People who study deeper about the first language have started their knowledge with their parents or social life in child period or stage with the pronunciation related with the first language. They learn about how the words are made and also how to say the words in a correct way - still known as pronunciation and how to pronounce 
the words. Persons with first language will master their language until the grown period; and this first language usually affected to the cultural language but not always be like this statement from Yule in 2010. The second language would talk about the formal language used in daily use. People take the second language in formal situation, to the people which they do not know really close, and also for the occasion situation. After all, the language and pronunciation are connected to each other as a part in communicating process and inside the process itself, the problems that occurred will be known as the process of getting the nature of language by the society of people. The problem inside these all statements that talks about the misspelling of phoneme, is definitely related to the phenomenon of misspelling phoneme area in phonology subject (Yule, 2010).

It is taken as the result of related study that the main public figure in the related speech made by Sandiaga Uno as the Indonesian, who has English as the foreign language, contained the misspelling phoneme in English. It can be stated that English is able to be spoken by the people with English as a foreign language acquisition. However, the problem in pronouncing clearly and correctly will still occur in some ways, as in the articulation place, articulation manner, and in the vowel side of phoneme material. This will create the understanding about how people in the area of foreign language like English has developed a different way in pronunciation clearly or with a different articulation area in misspelling phenomenon.

\section{CONCLUSION}

The area of misspelling phoneme in English is existent in the speech made by Sandiaga Uno. The misspelling phoneme occurred in the phonemes $/ \Lambda /$, $/ \mathrm{D} /, / \mathrm{\Theta} /, / \mathrm{\partial} /, / \Re /, / \mathrm{t} /$, and phoneme $/ \mathrm{d} 3 /$. These all phonemes are related to the articulation manner, articulation place, and also about the vowel, like the palatal and glottal area in phoneme sound. The phenomenon of misspelling phoneme happened related to the acquisition of language in a country or an area, background of the person, and also about the use of language for a special purpose. To create a better articulation in phoneme sound and also about the pronunciation, the better understanding of phonology and pronunciation in language is needed and has to be learnt by people and community in general, specifically for the people in the area of linguistic study and subject matter. Phonology which produces the pronunciation is pointed as the specific study to create a good sound pattern in speaking up the language towards the society who uses language as the tools for communication and creating a relation in social life.

\section{REFERENCES}

Ambalegin \& Arianto, T. (2019). A Phonology-based Study: English Pronunciation Inconsistency. $K n E$ Social Sciences, 2019, 106-124. https://doi.org/10.18502/kss.v3i19.4 834

\footnotetext{
Ambalegin, A., \& Hulu, F. (2019). Efl Learners' Phonological Interference of English Articulation. Jurnal Basis, 6(2), 145. https://doi.org/10.33884/basisupb.v6 i2. 1415
} 
John W. Creswell-Research Design_ Qualitative, Quantitative, and Mixed Method Approaches-SAGE

Publications (2013).pdf (p. 273). (2013).

Mcmahon, A. (2002). An Introduction to English Phonology-Edinburgh University Press (2001) (1).

Oxford advanced learner's dictionary (8th editio). (n.d.).

Sudaryanto. (2015). Metode dan aneka teknik analisis bahasa. Yogyakarta: Sanata Dharma University press.

Victoria Bull (Ed.). (2008). Oxford learner's pocket dictionary (fourth edi). New York: Oxford university press.

Yavas, M. (2011). Applied English phonology (Second edi). United Kingdom: Wiley-Blackwell.

Yule, G. (2010). The study of language (Fourth edi). UK: Cambridge University Press. 


\section{APPENDIX}

01. The name of the speech:

"Indonesia Billionaire Sandiaga

Uno on How Internet Could Help

Vast Rich-Poor Divide"

02. The utterance in the related

speech:

Sandiaga Uno: "I think, internet would be, a..., the way that some of the solutions that we want to present in term of providing access to the people at the bottom of the environment. For instance, internet can give a better access, to education." 